\title{
PUBLIC-PRIVATE SECTOR WAGE DIFFERENTIALS AND RETURNS TO EDUCATION IN DJIBOUTI
}

\author{
by
}

\author{
Paloma Anós Casero ${ }^{1}$ and Ganesh Seshan ${ }^{2}$
}

\begin{abstract}
Do public sector workers earn a wage premium in Djibouti and are the returns to education different across the sectors? Private and public sector wage earnings are estimated using 1996 household survey data, while controlling for selectivity using Heckman's two stage approach. The paper finds that Djiboutian public sector employees earn a wage premium, independent of their personal attributes and human capital endowments, and are more likely to be males and have parents in the public sector. Workers in the public sector earn higher private rates of return to education than do private sector workers with post-secondary schooling. These results raise concerns about the current government's hiring and wagesetting practices that generate distortions in the labor market and are not efficiently allocating labor and public resources.
\end{abstract}

Keywords: public/private wage differential, private returns to education, Djibouti

JEL Classification: J31, J45

\section{World Bank Policy Research Working Paper 3923, May 2006}

The Policy Research Working Paper Series disseminates the findings of work in progress to encourage the exchange of ideas about development issues. An objective of the series is to get the findings out quickly, even if the presentations are less than fully polished. The papers carry the names of the authors and should be cited accordingly. The findings, interpretations, and conclusions expressed in this paper are entirely those of the authors. They do not necessarily represent the view of the World Bank, its Executive Directors, or the countries they represent. Policy Research Working Papers are available online at http://econ.worldbank.org.

\footnotetext{
${ }^{1}$ Paloma Anós Casero is Senior Economist at the Social and Economic Development Group (MNSED), Middle East and North Africa Region, World Bank D.C. Email: panoscasero@worldbank.org

2 Ganesh Seshan is a consultant (ETC) at the Social and Economic Development Group (MNSED), Middle East and North Africa Region, World Bank. D.C. Email: gseshan@worldbank.org
} 


\section{Introduction}

The size of the public sector and its effects on private labor markets has motivated a good deal of research on the determination of the sectoral (public/private) wage process for paid employees in developed countries. Many studies have indicated significant differences in the wage structure in both sectors, with conditional and unconditional rewards in the public sector often exceeding those in the private sector. Policy initiatives to contain the growth of public-sector wages have been motivated by wage differentials established in these studies.

Much less is known about this issue for developing countries as noted by Christofides and Pashardes (2002), where in a number of countries large fiscal deficits have drawn attention to the public sector wage bill, often the largest component of public expenditure. A related concern voiced by Terrell (1993) is the impact of a large public sector on wage setting in the absence of strict market forces and whether it is having a 'spillover' effect on the remaining formal private sector where government pay scales serve as a standard for wage earners in the private sector. Indeed, in a number of developing countries, the public sector comprises a major part of the wage employment.

So is the case of Djibouti which is the focus of this paper - a low-income country where the public sector employs a disproportionate amount of the formal labor force at roughly 56.4 percent of the labor force, compared with 17.6 in the formal private sector. ${ }^{3}$ Throughout the 1990s, the annual average pay of a civil servant was about 10 times the country's GNI per capita and the average monthly civil servant wage was nearly 7 times higher than the minimum wage. Furthermore, Djibouti's public sector wages serve as a benchmark for private sector wages, which are higher than those earned in its neighboring countries. The public wage bill forms a significant component of the total government budget, averaging 50.8 percent of total expenditure in the 1990s. While some portion of the wage bill can be attributed to an oversized civil workforce, another component may be due to above competitive wage levels.

\footnotetext{
${ }^{3}$ This estimate is based on a 1996 representative household survey of the sedentary population. The labor force includes public and private workers (both formal and informal). If only public and private formal workers are considered, the public share is 76 percent and the private share is 24 percent.
} 
The purpose of this study is to determine whether or not Djibouti civil servants earn a wage premium above the private sector wage and whether there is a sectoral differential in terms of private returns to schooling. The average ratio of annual wages in the public sector to the formal private sector yields a wage differential of 1.1 using data from a 1996 representative household survey which is the only available sample of sedentary households in Djibouti that provides wage income information across various sectors and occupations ${ }^{4}$. However, using a simple average of the wage difference between public and private (formal) workers to determine whether there is a wage premium is misleading. Doing so does not address differences in human capital endowment and other personal or household characteristic that influence earnings. The methodology used in this study controls for these determinants while correcting for selectivity bias, which help accounts for factors that influence the sorting or queuing of workers into both sectors.

The results show that public sector employees earn a wage premium independent of their personal attributes and human capital endowments. The positive rent earned by the public sector is more likely due to the continuation of the legacy of French colonial rule, which paid high wages to the public sector. Workers in the public sector are also found to earn larger private rates of return to schooling than do private sector workers in the formal sector with post-primary education. However, higher private returns do not necessarily imply that that productivity is higher and hence better rewarded in the public sector.

The next section discusses the data and empirical methodology to derive parameters of earnings equations for workers in the public and private formal sector, based on which the existence of a rent can be inferred. Estimation results are provided in section three which is used to derive the wage premium and returns to education. Section four concludes.

\section{Econometric Model and Data}

While the adjusted wage differential could be computed as the ratio of average wages of workers employed in the public sector to the private sector, to make inferences about differences in wage of workers with similar human capital characteristics but employed in

\footnotetext{
${ }^{4}$ A small survey conducted by Bank staff in March 2005 led to a similar wage differential.
} 
different sectors, there is a need to estimate model of individual's earnings and sectoral choice as stated by Glinskaya and Lokshin (2005). The authors refer to three possible approaches. First, there is the Ordinary Least Square (OLS) regression relating wages to observable characteristics which adjusts for differences in human capital differences between workers in the public and private sector. Second, is a method to correct for selection in a sector where wage setting is a function of observable and unobservable characteristics of workers and employers. Third, there is a non-parametric technique called propensity score matching which is only beginning to be used in the literature measuring inter-sectoral wage differential. In this paper, the second approach is taken while contrasting the results with the first approach.

Studies of public-private wage differentials are based on models of earnings determination developing by Mincer (1974). Variations in earnings are due to differences in human capital, measured by formal schooling and work experience with controls including location and gender dummies. Assuming that there are two distinct labor markets: the public sector and formal private sector, denoted as 1 and 2 respectively, the corresponding wage functions are:

$$
\begin{aligned}
& \ln W_{1}=X \beta_{1}+\mu_{1} \\
& \ln W_{2}=X \beta_{2}+\mu_{2}
\end{aligned}
$$

where $\ln W_{i}$ is the natural $\log$ of wages in sector $i, \beta_{i}$ is the vector of coefficients associated with wage-determining attributes, $X$ and $\mu_{i}$ is a normally distributed disturbance term. More specifically the wage equation takes the follow form:

$$
\begin{aligned}
\ln W_{i j} & =\beta_{i 0}+\beta_{i 1} \text { PRIM }_{j}+\beta_{i 2} \text { MIDDLE }_{j}+\beta_{i 3} \text { SEC }_{j}+\beta_{i 4} \text { VOC }_{j}+\beta_{i 5} U N I V_{j} \\
& +\beta_{i 6} A G E_{j}+\beta_{i 7} A G E_{j}{ }^{2}+\beta_{i 8} \text { FEMALE }_{j}+\beta_{i 9} \text { MARRIED }_{j}+\beta_{i} L O C_{i j}+\mu_{i j}
\end{aligned},
$$

where $W_{i j}$ is the monthly earnings (in USD) for individual $j$ in sector $i$; PRIM, MIDDLE, SEC, VOC and UNIV are dummy variables indicating the highest level of education an 
individual has completed in either primary, middle schooling, secondary, vocational or university; $A G E$ and $A G E^{2}$ are age and age squared, FEMALE and MARRIED are dummy variables for female workers and married workers and $L O C$ are a set of location variables covering urban and rural areas.

The concern with estimating equations (1) or (2) using ordinary least squares (OLS) is that if some unobserved worker's characteristic that determine the wage are correlated with unobserved characteristic that determine the sector of employment, the results will be inconsistent. This is the selection bias problem that Heckman (1979) highlighted. As Stelcner et. al (1989) notes, OLS estimation without correcting for this implies that workers are randomly distributed between the public and private sector which is questionable if wage differential exists. In this case, workers may prefer one sector over the other and an endogenous selection process will determine the assignment of workers a sector.

The equations that determine sector participation -commonly referred to as the switching equations, can be stated as follows:

$$
\begin{aligned}
& I_{i}^{*}=\theta_{i} Z+\varepsilon_{i}, i=1,2 \\
& I_{1}=1 \text { (public sector) if } I_{1}^{*} \geq 0 \\
& I_{2}=1 \text { (private sector) if } I_{2}^{*} \geq 0 \\
& I_{i}=0, \text { otherwise, }
\end{aligned}
$$

where $I^{*}$ is a partially observed index that describes the selection process and the outcome is observed depending on whether $I^{*}$ is positive or negative. Vector $Z$ are variables that are affect the selection process which may be similar to $X$ in addition to exclusion restrictions that aid identification such as father's choice of job sector and unearned household income from remittances, benefits and rent. OLS estimation of equation (1) and (2) will provide unbiased estimates of wage levels only if $\varepsilon_{1}$ and $\varepsilon_{2}$ are uncorrelated with $\mu_{1}$ and $\mu_{2}$, respectively. If unobserved preferences or traits influence the selection process together with

\footnotetext{
${ }^{5}$ Dummies for nationality was excluded because it was found to be insignificant in subsequent regressions.
} 
the usual wage determinants, this assumption is violated and wage comparisons based on OLS are inconsistent.

Equations (4) and (5) summarize a selection process that involves two steps - a worker deciding on whether to obtain a public sector job and the employer determining if the person is suitable for the job. The worker compares the expected benefits with the cost of applying and the employer uses the characteristics of the applicants to select employee from a queue. Workers seeking a public wage offer and joining the public sector are observed, however we cannot differentiate between a worker who chose not to work in the public sector from a worker who did but was not accepted by the government employer. In the overall selection process, the difference in wages will affect the worker's choice while the applicant's personal characteristic will influence the employer's choice - hence a combination of variables that determine wages and other personal characteristics are used to form vector $Z$, which determines the selection process.

We adopt a two-stage estimation method where in the first stage, probit equations are estimated to determine variables that affect the probability of working in the public sector and private sector. A selection term, $\lambda_{i}$ (or the inverse Mills ratio) is constructed which is added to each wage equation. This allows the earnings regression to be estimated consistently using OLS, taking the follow form,

$$
\ln W_{i}=X \beta_{i}+\theta_{i} \lambda_{i}+\mu_{i}
$$

As a check of robustness, we estimate wage regression for both sectors, with and without the selection term. 
Data

Our analysis is based on the 1996 individual and household survey for Djibouti (EDAM 1996), which makes it possible to estimate individual returns to schooling and other wage determinants across various categories, including men, women, public, and private (formal sector). The sample is restricted to 2,011 wage earners between 12 and 65 years of age. Table 1 contains characteristics of the workers examined for this section, excluding employers.

Table 1: Selected Descriptive statistics of Djibouti Wage Earners in 1996

\begin{tabular}{|c|c|c|c|c|c|c|c|c|c|c|c|c|}
\hline \multirow[b]{2}{*}{ Variable } & \multicolumn{2}{|c|}{ All } & \multicolumn{2}{|c|}{ Male } & \multicolumn{2}{|c|}{ Female } & \multicolumn{2}{|c|}{ Public } & \multicolumn{2}{|c|}{ Private (Formal) } & \multicolumn{2}{|c|}{ Self-Employed } \\
\hline & Mean & STD & Mean & STD & Mean & STD & Mean & STD & Mean & STD & Mean & STD \\
\hline monthly wages/earnings (USD) & 288.2 & (373.5) & 354.5 & (362.6) & 168.8 & $(363.0)$ & 375.4 & (288.8) & 348.5 & $(262.5)$ & 240.0 & $(563.4)$ \\
\hline age & 35.0 & $(11.0)$ & 36.8 & $(10.7)$ & 31.7 & $(10.7)$ & 35.8 & $(10.4)$ & 34.7 & $(9.7)$ & 38.2 & $(11.7)$ \\
\hline female (\%) & 35.7 & & & & 100.0 & & 13.2 & & 30.0 & & 53.6 & \\
\hline married (\%) & 58.4 & & 74.6 & & 29.2 & & 69.9 & & 63.3 & & 58.5 & \\
\hline$\%$ in public sector & 43.6 & & 58.9 & & 16.2 & & & & & & & \\
\hline$\%$ in private (formal) sector & 13.4 & & 14.6 & & 11.3 & & & & & & & \\
\hline$\%$ in private (informal) sector & 20.0 & & 9.9 & & 38.3 & & & & & & & \\
\hline$\%$ self employed & 22.6 & & 16.3 & & 33.8 & & & & & & & \\
\hline$\%$ obtained certificate & 1.4 & & 1.5 & & 1.1 & & 2.2 & & 3.3 & & 0.0 & \\
\hline$\%$ with no formal education & 51.4 & & 40.8 & & 70.5 & & 47.1 & & 47.1 & & 74.8 & \\
\hline$\%$ with primary schooling & 18.3 & & 23.2 & & 9.5 & & 23.4 & & 26.3 & & 11.9 & \\
\hline$\%$ with middle schooling & 10.0 & & 11.4 & & 7.7 & & 15.2 & & 13.7 & & 3.3 & \\
\hline$\%$ with secondary schooling & 3.7 & & 4.4 & & 2.4 & & 5.6 & & 5.9 & & 1.8 & \\
\hline$\%$ with vocational schooling & 3.4 & & 3.9 & & 2.5 & & 5.4 & & 4.8 & & 0.9 & \\
\hline$\%$ with university education & 3.2 & & 4.6 & & 0.7 & & 5.4 & & 5.2 & & 0.7 & \\
\hline No of. Uncensored observations & 2011 & & 1293 & & 718 & & 878 & & 270 & & 453 & \\
\hline
\end{tabular}
Source: Author's calculation based on EDAMS 1996.

Wages are the sum of cash earnings. Monthly wages ${ }^{6}$ are obtained by dividing reported monthly wages by imputed monthly hours. The average monthly earning is USD 288 with males earning proportionally more on average (USD 354 vs. USD 169 for females). \%. Public sector monthly wages are on average higher by USD 26.9 relative to wages in the private formal sector.

Forty-three percent of workers are employed in the public sector, 14 percent in the private formal sector, and 22 percent in the informal sector. Males make up 64.3 percent of overall wage earners. More than 75 percent of male workers are married and more than 58 percent work in the public sector. In contrast, 74 percent of female workers are unmarried and only

${ }^{6}$ Daily wages are converted in monthly figures by multiplying with 26 days. Similarly weekly wages are converted to monthly wages by multiplying with 4.2 weeks. 
16.2 percent work in the public sector. 53.6 percent of the workers in the informal sector are women, with nearly 75 percent having no formal education. A relatively larger proportion of females are found in the private sector at $30 \%$ compared to $13 \%$ in the public sector.

With respect to education attainment, half of Djibouti wage earners have no formal education while 18\% have completed primary schooling. Lack of formal education is disproportionately higher among female workers at $71 \%$ compared to males at $40.8 \%$. A final observation pertains to income volatility. Income earned by informal sector workers is far more variable that that earned by workers in the public and private sector, as seen by the standard deviation in monthly earnings.

The next section explores factors that affect an individual's decision to participate in public or private sector employment. The characteristics that affect participation are then used to adjust the outcome of earnings regression for each sector (ie. the selectivity adjusted approach). The results of the regression are used to determine if there is a public sector wage premium after controlling for human capital endowment and differences in private returns to education across sectors.

\section{Estimation results}

\section{1 Labor market participation equation}

This sub-section determines the extent to which factors such as education attainment, experience, gender and parent's occupation influence sectoral choices of workers. Participation equations are estimated using the probit model with the outcomes shown in Table 2. The results provide the marginal effects or the probability of each variable of joining the public or formal private sector calculated at the mean values of the variables. For comparison purposes, the participation choice for self-employed workers is also included.

The relationship between age and labor force participation is non-linear across all three sectors. For workers in the public sector, the probability of participation increases until an 
individual is 42.3 years and then starts decreasing. The turning point is similar for individuals in the private sector (at 40 years) and who are self-employed (at 43.8 years).

Education affects positively participation into public and private sectors and reduces the likelihood of participation in the informal sector. Workers with university education have a higher probability of joining the public sector as opposed to the formal private sector. The older a worker which serves as a proxy for more work experience, the higher the probability of joining each sector. Females are less likely to participate in the formal sector and are more likely to be in the informal sector.

Having a parent in the public sector raised the probability of finding employment in the public sector and reduce the probability of being in the informal sector. Income effects on participation, measured by unearned household income is statistically significant and negative as expected for public and private sector workers since higher non-labor income would reduce the need to seek formal employment.

Table 2 Djibouti: Public and Private Sector Participation Equation

\begin{tabular}{|c|c|c|c|c|c|c|}
\hline \multirow[b]{2}{*}{ Variables } & \multicolumn{2}{|l|}{ Public } & \multicolumn{2}{|c|}{ Private Formal } & \multicolumn{2}{|c|}{ Self-Employed } \\
\hline & $\begin{array}{c}\text { Marginal } \\
\text { Effect }\end{array}$ & $\begin{array}{l}\text { Std. } \\
\text { Dev }\end{array}$ & $\begin{array}{c}\text { Marginal } \\
\text { Effect }\end{array}$ & $\begin{array}{l}\text { Std. } \\
\text { Dev }\end{array}$ & $\begin{array}{c}\text { Marginal } \\
\text { Effect }\end{array}$ & $\begin{array}{l}\text { Std. } \\
\text { Dev }\end{array}$ \\
\hline age & 0.011 *** & $(0.00)$ & $0.004 * \star *$ & $(0.00)$ & $0.007 \star \star \star$ & $(0.00)$ \\
\hline age squared/100 & $-0.013 * \star * *$ & $(0.00)$ & $-0.005 * \star \star$ & $(0.00)$ & $-0.008 * \star *$ & $(0.00)$ \\
\hline female & $-0.068 * \star \star$ & (0.01) & $-0.008 * * \star$ & $(0.00)$ & $0.009 * \star *$ & $(0.00)$ \\
\hline married & $0.009 * \star$ & (0.00) & 0.001 & $(0.00)$ & $-0.009 * * *$ & $(0.00)$ \\
\hline obtained certificate & $0.048 * \star \star$ & (0.02) & $0.039 * * *$ & $(0.02)$ & & \\
\hline primary schooling & $0.042 * \star \star$ & (0.01) & $0.014 * * *$ & $(0.00)$ & $-0.009 * *$ & $(0.00)$ \\
\hline middle schooling & $0.106 * \star *$ & (0.02) & $0.020 * * *$ & $(0.01)$ & $-0.014 * *$ & $(0.00)$ \\
\hline secondary schooling & $0.134 * \star \star$ & (0.03) & $0.028 * * *$ & $(0.01)$ & -0.004 & $(0.01)$ \\
\hline vocation training & $0.144 * \star \star$ & (0.03) & 0.016 ** & $(0.01)$ & -0.014 & $(0.01)$ \\
\hline university & $0.138 * \star \star$ & (0.04) & $0.023 * * *$ & (0.01) & $-0.022 * *$ & $(0.00)$ \\
\hline parents work in public sector & $0.010 * *$ & $(0.00)$ & -0.002 & $(0.00)$ & -0.011 ** & $(0.00)$ \\
\hline parents work in private sector & $-0.013 *$ & (0.01) & -0.003 & $(0.00)$ & $-0.019 * * \star$ & $(0.00)$ \\
\hline In_unearned income & $-0.005 * \star \star$ & $(0.00)$ & 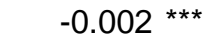 & $(0.00)$ & -0.001 & $(0.00)$ \\
\hline Pseudo R square & 0.33 & & 0.19 & & 0.15 & \\
\hline
\end{tabular}

Note: standard errors are in brackets. ${ }^{\star \star \star}$ denotes statistical significance at $1 \%$ level, ${ }^{\star \star}$ at $5 \%$ and ${ }^{\star}$ at $10 \%$.

Source: Authors' estimates based on EDAM 1996. 


\subsection{Wage equation}

A wage regression using the Mincer framework is often used to calculate the private returns to education and the degree to which other individual characteristics may influence earnings. The model is estimated for public and private wage earners using OLS with and without conditioning on selection choice. Inclusion of the selection term which is constructed from the earlier participation equation controls for the fact that workers do not randomly work in either sector allows us to test whether factors influencing the sorting of workers into these two sectors also affect wage earnings. The independent variables common to each wage regression are dummies variables for rural and urban locations, for completing education at various levels, for age, for females and for marriage.

Experience exerts a positive influence on wage offers particularly in the private sector. The results are presented in Table 3. The coefficient magnitudes differ for both specifications and indicate the importance of correcting for selectivity. Referring to the selectivity corrected earnings regressions, experience exerts a positive influence on wage offers while the quadratic term has the expected negative sign. The curvature of the wage-experience profile is steeper in the private sector than in the public sector, which is consistent with the general pattern in many countries.

Being female has a negative impact on wages in the private sector. The coefficient on female workers in the private sector is negative and statistically significant implying that female workers face an earnings penalty in the private sector. No clear conclusions could be drawn about females in the public sector given the statistically insignificant of the female coefficient. The data for similar profession such as biologist, teachers and administrative agents, show that males earned more on average.

Marriage has a positive impact on wage offers in the private sector. This may be due to reduced absenteeism or lower monitoring cost associated with married workers. The coefficients for schooling attainment will be discussed in the next section. 
Private sector workers have higher productivity than the average worker in the labor market. By contrast, public workers have below average productivity. The coefficient estimates of the selection term for individuals were statistically significant, being negative in the public sector and positive in the private sector. The positive coefficient for the private sector indicates that individuals who select jobs in the private sector have higher productivity than the average worker while the negative coefficient for public sector workers imply that they have lower productivity that the average worker.

Table 3 Djibouti: Log Wage Equations for the Public and Private Sector

\begin{tabular}{|c|c|c|c|c|c|c|c|c|c|}
\hline \multirow{2}{*}{ Variables } & \multicolumn{4}{|c|}{ Selectivity Corrected Regression } & \multicolumn{5}{|c|}{ OLS Regression } \\
\hline & \multicolumn{2}{|c|}{ Public } & \multicolumn{2}{|c|}{ Private } & \multicolumn{3}{|c|}{ Public } & \multicolumn{2}{|c|}{ Private } \\
\hline$\overline{\text { age }}$ & 0.007 & $(0.02)$ & 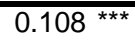 & $(0.03)$ & 0.047 & ** & $(0.02)$ & 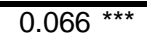 & $(0.02)$ \\
\hline age squared/100 & 0.011 & $(0.03)$ & $-0.123 * \star *$ & $(0.04)$ & -0.037 & * & $(0.02)$ & -0.072 ** & $(0.03)$ \\
\hline female dummy & 0.176 & (0.11) & $-0.424 * * *$ & (0.10) & -0.059 & & $(0.06)$ & $-0.314 * \star \star$ & (0.07) \\
\hline married dummy & 0.101 & (0.06) & $0.220 * *$ & (0.09) & 0.183 & $\star \star \star *$ & $(0.06)$ & 0.201 ** & (0.09) \\
\hline primary school & $0.141 * \star$ & $(0.06)$ & 0.402 *** & (0.11) & 0.233 & $\star * \star$ & $(0.05)$ & $0.280 * \star \star$ & (0.08) \\
\hline middle school & $0.375 * \star \star$ & $(0.10)$ & $0.756 * \star \star$ & $(0.14)$ & 0.551 & 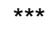 & (0.07) & $0.613 * \star \star$ & $(0.13)$ \\
\hline high school & $0.670 * \star \star$ & (0.12) & $0.954 * \star *$ & (0.19) & 0.856 & 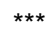 & (0.07) & $0.751 * \star \star$ & (0.10) \\
\hline vocational training & 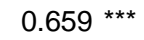 & (0.13) & $0.815 * \star *$ & (0.18) & 0.870 & $\star \star \star *$ & $(0.06)$ & $0.667 * \star \star$ & (0.19) \\
\hline university & $0.942 * \star *$ & $(0.12)$ & $0.977 * * *$ & (0.18) & 1.137 & $* * *$ & (0.09) & $0.822 * \star \star$ & (0.14) \\
\hline constant & $5.603 * \star *$ & (0.57) & $2.747^{\star \star *}$ & (0.93) & 4.376 & 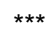 & $(0.28)$ & $4.164 * \star \star$ & (0.42) \\
\hline selection term & -0.274 ** & (0.11) & 0.318 * & (0.18) & - & - & - & - & - \\
\hline
\end{tabular}

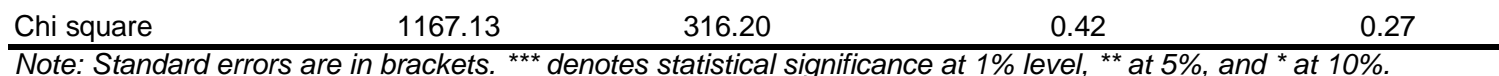
Source: Authors' estimates based on EDAM 1996.

\subsection{Public-private wage differential decomposition}

Using a simple average of the wage difference between public and private (formal) workers to determine whether there is a wage premium is misleading, because doing so does not account for differences in human capital endowment and other personal or household characteristics that influences earnings. It is possible to breakdown various components that contribute to the difference between predicted public and private sector wages using an Oxaca-Blinder decomposition. There are four possible components, including the differential caused by selectivity bias, 


$$
\begin{aligned}
\ln \bar{W}_{\text {pub }}-\ln \bar{W}_{p v t} & =\underbrace{\left(\beta_{p u b, 0}-\beta_{p v t, 0}\right)}_{\text {premium }}+\underbrace{0.5\left(\beta_{\text {pub }}+\beta_{p v}\right)\left(\bar{X}_{p u b}-\bar{X}_{p v t}\right)}_{\text {endowment }}+\underbrace{0.5\left(\bar{X}_{p u b}+\bar{X}_{p v t}\right)\left(\beta_{p u b}-\beta_{p v t}\right)}_{\text {returns }} \\
& +\underbrace{\theta_{p u b} \bar{\lambda}_{p u b}-\theta_{p u b} \bar{\lambda}_{p v t}}_{\text {selection }}
\end{aligned}
$$

where bars denotes the mean of the variables. Subscripts pub refers to the public sector while pvt denotes the private (formal sector). The first component is the difference in the base wage (constant term) which is often understood as the premium or pure rent from being in the public sector. The second component is due to difference in human capital endowment of the workers. The third is due to the difference in private returns to the endowments and the final component is due to the difference in the selection terms.

Table 4 shows the decomposition results for Djibouti with and without conditioning on selection. Both methods clearly show that the most important factor determining a positive wage differential in favor of public sector wages is a wage premium or rent. The premium is much larger when characteristics that determine participation in both sectors are controlled, as captured in the second column.

Table 4 Djibouti: Mean Log Wage Differential between Public and Private (formal) Sector

\begin{tabular}{lcc}
\hline & OLS & $\begin{array}{c}\text { Selectivity } \\
\text { Corrected }\end{array}$ \\
\hline Total log mean differential & 0.41 & 0.04 \\
Components attributable to: & & \\
$\quad$ Wage premium & 0.21 & 2.86 \\
$\quad$ Human capital endowments & 0.34 & -0.06 \\
$\quad$ Market returns & -0.15 & -1.80 \\
$\quad$ Selection & & -0.95 \\
\hline Total unexplained differential & 0.06 & 1.06 \\
\hline Source: Authors' calculations based on wage regressions in Table 5. & &
\end{tabular}

Source: Authors' calculations based on wage regressions in Table 5.

Hence in Djibouti, public sector workers earn a rent, after controlling for other wage determinants. Terrell(1993) found in Haiti that public administration workers earned a sizeable rent. Similarly, Lindauer and Sabot (1983) found that the wage premium was the most important determinant of public-private wage differential in Tanzania. The positive rent earned by the public sector in Djibouti is more likely due to the legacy of French 
colonial rule, which paid high wages to the public sector and rewarded the patronage and loyalty of the elite class.

\subsection{Private returns to education}

Aside from higher base wages for government work, differences in returns to schooling for workers in the public and private sectors may also help explain the queuing for public employment. The results from the earnings functions can be used to estimate private rate of return to each level of schooling. The private returns to schooling, $r$ to different levels of schooling can be computed as follows for each sector, $i$ :

$$
\begin{aligned}
& r(\text { prim })_{i}=B_{i 1} / S_{\text {PREM }} \\
& r(\text { middle })=\left(B_{2}-B_{1}\right) / S_{\text {MIDDLE }} \\
& r(\mathrm{sec})=\left(B_{3}-B_{2}\right) / S_{\text {SEC }} \\
& r(\text { vOC })=\left(B_{4}-B_{2}\right) / S_{\text {VOC }} \\
& r(\text { univ })=\left(B_{5}-B_{3}\right) / S_{\text {UNIV }}
\end{aligned}
$$

where the length in years of each schooling level is given by , $S_{P R I M}=6, S_{M I D D L E}=4, S_{S E C}=3$, $S_{V O C}=3$ and $S_{U N I V}=3^{7}$.

Table 5 presents the computed private wage returns per year of schooling for different education levels completed in the public and private (formal) sector using results from the previous wage regressions. While the focus is on the first two columns which utilizes coefficients from the selectivity correct wage equations, the returns are also computed using OLS coefficients for comparison.

\footnotetext{
${ }^{7}$ Most Djiboutians earned their university degree abroad in France. A basic degree takes 3 years which is the average length assumed for individuals indicating they have earned a foreign degree in the sample.
} 
Table 5 Djibouti: Annual Private Returns to Education in Public and Private Sector

\begin{tabular}{lccccc}
\hline & \multicolumn{2}{c}{$\begin{array}{c}\text { Selectivity-Corrected } \\
\text { Regression }\end{array}$} & & \multicolumn{2}{c}{ OLS Regression } \\
\cline { 2 - 3 } \cline { 5 - 6 } & Public & Private & & Public & Private \\
\hline Primary & 2.4 & 6.7 & & 3.9 & 4.7 \\
Middle & 5.8 & 8.9 & & 8.0 & 8.3 \\
Secondary & 9.9 & 6.6 & & 10.2 & 4.6 \\
Vocational & 9.5 & 2.0 & & 10.6 & 1.8 \\
University & 9.0 & 0.8 & & 9.4 & 2.4 \\
\hline
\end{tabular}

Note. Estimates for primary category is the earnings premium over no-formal education. Similarly, middle school category shows earning differential over primary school. Secondary category shows differential over middle school, vocational shows differential over middle school and university is the differential over secondary school.

Source: Authors' calculations based on wage regressions from Table 3.

Workers in the public sector earn larger annual private rates of return to schooling than do private sector workers with secondary, vocational and university education. For wage earners in the private sector, the annual private return to education peaks at 8.9 percent after completion of middle schooling, compared with 5.8 percent for those in the public sector. The annual private return to secondary schooling is 6.6 per year of schooling for wage earners in the private sector relative to 9.9 percent for those in the public sector. The annual returns for private sector wage earners with vocational training drops to 2 percent, compared with 9.5 percent for public sector workers with the same qualification. Returns to education for workers with university level education are much higher in the public sector than in the private sector. The annual private returns of moving from high school to university education 0.8 percent compared to 9 percent for graduates working in the public sector.

As illustrated earlier, higher private returns do not, however, signal that productivity is higher (and hence better rewarded) in the public sector. The higher returns to education in the public sector are explained by the distorting government pay policies, and the legacy of rewarding educated labor for patronage and loyalty to the ruling elite and the lack of viable job opportunities in the private sector for educated workers.

Average returns to education in Djibouti can also be examined for all workers and for males and females separately. Separate wage regressions corrected for selectivity are shown in Table 6 while Table 7 provides results using the approach in (7) for the working population engaged in various sectors correcting for selectivity bias. 
Table 6 Djibouti: Selectivity Corrected Wage Equations

\begin{tabular}{|c|c|c|c|c|c|c|c|c|c|}
\hline \multirow{2}{*}{$\frac{\text { Variables }}{\text { age }}$} & \multicolumn{2}{|l|}{ All } & \multicolumn{2}{|c|}{ All (years of edu.) } & \multicolumn{3}{|c|}{ Male } & \multicolumn{2}{|l|}{ Female } \\
\hline & $0.095 * \star \star$ & $(0.03)$ & $0.103^{\star \star \star}$ & $(0.03)$ & 0.133 & $\star \star \star$ & $(0.03)$ & 0.105 * & $\overline{(0.06)}$ \\
\hline age squared/100 & $-0.104 * * \star$ & (0.03) & $-0.109 * \star \star$ & (0.03) & -0.144 & $\star \star \star \star ~$ & $(0.04)$ & -0.131 * & (0.08) \\
\hline female dummy & $-0.875 * \star *$ & $(0.09)$ & $-0.783 * * *$ & (0.09) & & & & & \\
\hline married dummy & $0.260 * \star \star$ & $(0.05)$ & $0.270 * \star \star$ & (0.05) & 0.273 & $\star *$ & $(0.12)$ & 0.067 & $(0.23)$ \\
\hline primary school & $0.597 * \star \star$ & $(0.06)$ & - & - & 0.492 & $\star \star \star \star ~$ & (0.07) & $0.908 * \star *$ & (0.14) \\
\hline middle school & $1.003 * * \star$ & (0.09) & - & - & 0.787 & $\star \star \star \star ~$ & (0.10) & $1.533 * \star \star$ & $(0.20)$ \\
\hline high school & $1.328 * * *$ & (0.13) & - & - & 1.184 & 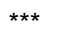 & $(0.14)$ & $1.795 * * *$ & (0.31) \\
\hline vocational training & $1.348 * * *$ & (0.13) & - & - & 1.166 & $\star \star \star ~$ & $(0.15)$ & $1.860 * * *$ & (0.27) \\
\hline university & $1.596 * \star \star$ & $(0.14)$ & - & - & 1.500 & $\star \star \star \star ~$ & $(0.14)$ & $1.923 * \star \star$ & $(0.45)$ \\
\hline constant & $2.923 * * *$ & (0.67) & - & - & 2.177 & $\star \star \star$ & $(0.79)$ & 1.838 & (1.55) \\
\hline selection term & 0.345 ** & $(0.17)$ & $0.367 * *$ & $(0.16)$ & 0.377 & ** & (0.18) & 0.470 & (0.41) \\
\hline years of education & - & 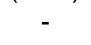 & $0.116 * \star \star$ & $(0.01)$ & & & & & \\
\hline Chi square & 2006. & & 2027. & & & 7.17 & & 779.65 & \\
\hline No. of uncensored obs. & 201 & & 199 & & & 293 & & 718 & \\
\hline
\end{tabular}

Table 7 Djibouti: Selectivity-Corrected Annual Private Rate of Returns to Schooling, 1996

\begin{tabular}{lccccc}
\hline \multicolumn{1}{c}{ Education Level } & All & Males & Females & Public & Private \\
\hline Primary & 10.0 & 8.2 & 15.1 & 2.4 & 6.7 \\
Middle & 10.2 & 7.4 & 15.6 & 5.8 & 8.9 \\
Secondary & 10.8 & 13.2 & 8.7 & 9.9 & 6.6 \\
Vocational & 11.5 & 12.6 & 10.9 & 9.5 & 2.0 \\
University & 8.9 & 10.5 & 4.3 & 9.0 & 0.8 \\
years of education & & & & & \\
\hline
\end{tabular}

Note. Estimates for primary category is the earnings premium over no-formal education. Similarly, middle school category shows earning differential over primary school. Secondary category shows differential over middle school, vocational shows differential over middle school and university is the differential over secondary school.

Source: Authors' calculations based on wage regressions from Tables 3 and 6

An additional year of schooling, corrected for worker's sector allocation, raises earnings by 11.6 percent - higher than the world average of 10 percent $^{8}$. This figure may be overstated as it does not account for years of repetition which is high in Djibouti, particularly for secondary education. When compared to other African countries such as Ghana, Cote D'Ivoire and Kenya, returns in Djibouti to secondary and university schooling are lower (Schultz, 2003). In addition, the analysis of public and private wages in Djibouti revealed that private returns depend whether the worker is employed in the public sector or in the private sector. Estimates on private returns to education should be treated with caution, and future work should provide more accurate estimates by sector as well as control for selection bias.

\footnotetext{
${ }^{8}$ See Psacharopoulos (1994) for world averages.
} 
Female workers who have completed primary and middle schooling earn relatively higher returns than their male counterparts. By contrast, male workers who have completed secondary schooling and tertiary education have higher returns to education than women. Returns are almost double for females relative to males completing primary and middle school, at an annual rate of 15.1 percent and 15.6 percent, respectively. However, this reverses with secondary schooling and higher levels of education. Males receive higher returns on having completed secondary schooling and tertiary education.

An alternative approach to measuring schooling returns is to observe the total differential private rate of return from completing an education level which is provided in Table 8. Looking at the final row, males enjoy a 31.6 percent return on completing a basic 3 year foreign university education over and above the return from secondary schooling. The total private returns to females having completed university education holding all else constant are less than half of their male counterpart at 12.8 percent. Most obvious is the disparity in private returns to university education between public and private sector workers. Public workers earn over 10 times the private returns of private sector employees with tertiary education'. For public sector employees who earn a 5 year foreign Master's degree, their private returns would be as high as 45 percent.

Table 8 Djibouti: Selectivity-Corrected Total Private Rate of Returns to Schooling, 1996

\begin{tabular}{lccccc}
\hline \multicolumn{1}{c}{ Education Level } & All & Males & Females & Public & Private \\
\hline Primary & 59.7 & 49.2 & 90.8 & 14.1 & 40.2 \\
Middle & 40.6 & 29.6 & 62.4 & 23.3 & 35.4 \\
Secondary & 32.5 & 39.6 & 26.2 & 29.6 & 19.8 \\
Vocational & 34.4 & 37.8 & 32.7 & 28.4 & 5.9 \\
University & 26.8 & 31.6 & 12.8 & 27.1 & 2.3 \\
& & & & & \\
\hline
\end{tabular}

Note. Estimates for primary category is the earnings premium over no-formal education. Similarly, middle school category shows earning differential over primary school. Secondary category shows differential over middle school, vocational shows differential over middle school and university is the differential over secondary school.

Source: Authors' calculations based on wage regressions from Tables 3 and 6

\footnotetext{
${ }^{9}$ There is also a large gap in returns between individuals who completed university education and those with vocational training. The total post middle-school private returns for university degree holders in the public sector is 56.7 percent compared to 28.4 percent for those with vocational schooling. In the formal private sector, the post middle-school returns to education for university degree holders is 22 percent compared to 6 percent for individuals who completed vocational training.
} 


\section{Conclusion}

After controlling for differences in education, experience, and selectivity bias, large publicprivate wage differentials still exist in Djibouti. The source of this difference is the rent or wage premium for public sector workers. Given that these differentials are estimated with wages net of fringe benefits and given that the public sector has higher benefits (leave time, health benefits, and so on), the estimated rents or base wages can be viewed as conservative.

The results from the estimation of the selection process and its effect on wages seem to indicate that there are barriers to entry into the public sector. Public sector employees are more likely to be male and to come from the elite class, with parents in the public sector. The policy implications from this analysis are that the public sector hiring and wage-setting practices generate distortions in the labor market and are not efficiently allocating labor and

public resources. At the same time, they are undermining the country's competitiveness by serving as a benchmark for high private sector wages. 


\section{References:}

Christofides, L. and Pashardes, P. (2002), "Self/paid employment, public/private sector selection, and wage differentials", Labor Economics, vol. 9: 737-762

Glinskaya, E. and Lokshin, M. (2005), "Wage Differentials Between the Public and Private Sectors in India”, World Bank Policy Research Paper 3574.

Heckman, J. (1979), "Sample selection bias as a specification error", Econometrica, vol. 47: 53161.

Lindauer, D.L. and Sabot, R.H. (1983), "The Public-Private Wage Differential in a Poor Urban Economy", Journal of Development Economics, vol. 12(3):137-157.

Psacharopoulos, George (1994) "Returns to Investment in Education: A Global Update." World Development 22(9): 1325-1343.

Psacharopoulos, George (1996) "RR Manual: A Program to Estimate the Rate of Return to Investment in Education." The World Bank. Washington, D.C.

Schultz, P. (2003), "Evidence of Returns to Schooling in Africa From Household Surveys : Monitoring and Restructuring the Market for Education", Yale Economic Growth Center Discussion Paper No. 875.

Stelcner, M., van der Gaag, J. and Vijverberg, W. (1989), "A Switching Regression Model of Public-Private Sector Wage Differentials in Peru: 1985-1986", Journal of Human Resources, Vol. 24(3): 545-559.

Tansil, A. (1999), "Public-Private Employment Choice, Wage Differentials and Gender in Turkey”, Yale Economic Growth Center Discussion Paper No. 797.

Terrell, K. (1993), "Public-private wage differential in Haiti", Journal of Development Economics, vol. 42: 293-314. 